compulsory for all pilgrims attending the great religious festivals, during which cholera had formerly so often been epidemic. Under British rule such a measure would probably have been unacceptable to the people.

In leprosy he started from the knowledge that chaulmoogra oil had some reputation for beneficial action, but was difficult to administer, and he isolated from it sodium gynocardate, which could be given more easily, and proved to be relatively effective. This remained the main basis of treatment until the sulphones were introduced.

Rogers undertook research on several other problems-snake venom, trypanosomiasis of horses, and other subjects-and devoted his inexhaustible energy to raising funds for a School of Tropical Medicine in Calcutta, which was opened in 1916; it remains an active institution and a permanent memorial to him.

He returned from India in 1920, was appointed medical adviser to the Secretary of State for India and physician to the Tropical Diseases Hospital; but the main interest of his later life was the British Empire Leprosy Relief Association, to which he gave large sums of his own well-earned money and time. $\mathrm{He}$ was president of the Royal Society of Tropical Medicine and Hygiene during 1933-35.

Rogers received many honours, as the list of his distinctions shows, and his work was well acknowledged in his lifetime, but he remained frugal in his habits, simple and even austere in his private life. He loved walking and cycling, not probably for the opportunities these gave of appreciating the beauty of Nature so much as for the release of energy they involved. Apart from his family he had few interests outside his work, but this work enraptured him, as he admitted in his autobiography, Happy Toil. He remained a religious man, but he also retained a critical, caustic mind, enthusiastic and resilient. His knowledge was exact, and he was at home with figures, which he could produce from memory on any public platform. Ho had immense innate authority, and at the same time a sense of fun, and he did not act tho part of a great public figure-he was always himself, a single-minded scientist with the egocentrieity which is part of genius. He was a very great man.

He married, in 1914, Una Elsie North, by whom he had three sons, who survive him, and he was ideally happy with her. Charles Wilcocks

$$
\text { Dr. B. P. Eddy }
$$

Dr. B. P. EDDx died in Cambridge on August 11 at the age of thirty-seven, tragically cutting short a promising caroer in microbiology and leaving his many friends and colleagues with a deep sense of loss. Brian Pollard Eddy was born in Newcastle upon Tyne and received his education there; first at the Royal Grammar School (1936-43) and then, by virtue of an open scholarship, at King's Colloge, Newcestle. After graduating with first-class honours in botany he was awarded the Pemberton postgraduate studentship. During its tenure for two years he did research on the formation of anthocyanins under Prof. Meirion Thomas.

In 1948 he was invited to fill a vacancy which existed for a bacteriologist at the Low Temperature Rosearch Station, Cambridge, and he joined the staff in November of that year. While attending courses in bacteriology he completed his work on anthocyanins and was awarded the degree of Ph.D. of the University of Durham in 1949.
His work on problems rolating to food began with a study of the bacterial reduction of dehydroascorbic acid. He showed that, in the bacterial cell, this depended on a rather specific activating enzyme and a particular type of cytochrome complement. $\mathrm{He}$ then turned to the problem of using micro-organisms for the production of new food materials. An attempt was made to produce dried 'mushroom' powder by the deep tank culture of various Basiodiomycetes. Though acceptable powders were made, the desirable 'mushroom' flavour was absont. The mass cultivation of algae was also studied. Dunaliella, rather than Chlorella, was selected because it does not develop a prominent (and indigestible) cell wall and it was established that yields and growth rates were com. parable with those of Chlorella.

Eddy's interest in the bacterial production of nitrite lod him to investigate problems of meat curing. It was with this background that he edited the proceedings of the second International Symposium on Food Microbiology on the subject of "The Microbiology of Fish and Meat Curing Brines" (H.M.S.O., London, 1958). His recent activities in this sphere related to problems arising from the introduction of the new process of vacuum packing sliced bacon.

In the past few years, Eddy was especially interested in the physiology of Gram-negative bacteria. His recent revision of the genus Aeromonas, on which he was actively engaged at the time of his death, was probably his best known work. He published more than thirty papers, many jointly with colleagues in the Low Temperature Research Station, who will miss his co-operation. They will also miss his untiring efforts on the committee of the local branch of the Institution of Professional Civil Servants. His principal hobbies were music, of which he was passionately fond, and photography.

He was not strong physically and was for this reason exempt from War service. Temperamentally he was highly strung. However, he was throughout his university and research careors a likeable and sincere colleague, and it is as such that he is remembered.

E. C. BATE-SMITH

\section{Mr. C. C. Calder}

Charles Cumming Calder, who died in Aberdeen in April 1962, was one of a long and distinguished line of Scots who held high botanical office in India, and threo of his immediate predecessors, Sir George King, Sir David Prain (later director of the Royal Botanic Gardens, Kew) and Colonel A. T. Gage were, like himself, graduates of the University of Aberdeen. Calder was born at Dunphail in Morayshire in December 1884, and was educated at Robert Gordons College, Aberdeen, and later at the University, where he took the degree of B.Sc. both in pure science and in agriculture. After graduation he went for a period of study to Berlin and on his return to Aberdeen he was for a time assistant to Prof. J. W. TI. Trail, who was a close friend of King, to whom he had recommonded young Prain for appointment to the Indian service. Trail no doubt influenced Calder in accepting the post of curator of the Herbarium at Sibpur in March, 1912, where he remained, apart from a short period on active service in 1918, until his appointment in January, 1923, as superintendent of the Royal Botanic Gardens, Calcutta, conjointly with the directorship of the Indian Botanical Survey. Another 